\title{
Handmaidens of the legislature? Understanding regulatory timing
}

\author{
Simon F. Haeder ${ }^{1 \star(D)}$ and Susan Webb Yackee ${ }^{2}$ \\ ${ }^{1}$ Assistant Professor of Public Policy, The Pennsylvania State University, 329 Pond Lab, University Park, \\ 16802, USA and ${ }^{2}$ Professor of Political Science and Public Affairs, University of Wisconsin-Madison, \\ 1225 Observatory Drive, Madison, 53706, USA \\ ${ }^{*}$ Corresponding author. Email: sfh5482@psu.edu
}

(Received 19 May 2020; revised 24 April 2021; accepted 19 July 2021; first published online 13 January 2022)

\begin{abstract}
When does legislation trigger regulation? The US Congress regularly passes laws that authorise government agencies to write legally binding regulations. Yet, when this occurs, agencies may take years to act - or, at times - may never act at all. We theorise that the breadth of the congressional statutory delegation drives the timing of agency policy production. In particular, when Congress expressly tells an agency to promulgate a rule, we expect agencies to do so quickly. Yet, when Congress provides greater policymaking discretion to agencies, we expect other factors - and especially, internal agency considerations - to drive regulatory timing. We use data from almost 350 statutes spanning four decades, which are then matched up with thousands of regulations, to assess the argument. Using innovative methods, we find support for our hypotheses. Overall, we produce a deeper understanding of the link between delegation and discretion: suggesting when it occurs, as well as, importantly, why.
\end{abstract}

Key words: bureaucracy; Congress; oversight; policymaking, and delegation; regulation

Public agencies are the policy handmaidens of legislatures. Or are they? In the United States (US), federal agencies routinely issue legally binding government regulations (also called "rules") that provide the detail necessary to implement, enforce and enable the laws passed by Congress and signed by the president. Such regulations are critical governance tools; in fact, "[i]t is to rules, not to statutes or other containers of the law, that we turn most often for an understanding of what is expected of us and what we can expect from government" (Kerwin and Furlong 2018). Yet, a strong case can be made that puts legislatures in the driver's seat of the agency policymaking process (McCubbins 1985; Bawn 1997; Huber et al. 2001; West and Raso 2013). In particular, Congress controls the delegation of rulemaking authority to federal agencies, and agencies are prohibited from writing rules unless they have legislative permission to do so (West 1995; Haeder and Yackee 2015; Rosenbloom 2018).

(C) The Author(s), 2022. Published by Cambridge University Press. This is an Open Access article, distributed under the terms of the Creative Commons Attribution licence (http://creativecommons.org/licenses/by/4.0/), which permits unrestricted re-use, distribution and reproduction, provided the original article is properly cited. 
While this summation - which suggests the primacy of Congress - may be technically accurate, it also provides an incomplete picture. In particular, it ignores the fact that agencies generally control the timing of agency action, which is, in and of itself, a political decision (Carpenter 2002; Carpenter et al. 2012; Callander and Krehbiel 2014; Potter 2019; Haeder and Yackee 2020a, 2020b). In this article, we demonstrate that agencies routinely take years, even decades, to issue regulations in response to statutory delegations of rulemaking authority. This raises a number of questions, including how much democratic control does legislation - and hence Congress - really hold over agency rulemaking? And, under what conditions are agencies more (or less) responsive to congressional demand for regulation? We provide new answers to these old questions by focusing on the passage of time between: (1) a congressional statute delegating new rulemaking authority to an agency and (2) the agency's first draft rule using that delegated authority. In doing so, we assess empirically the political, agency and environmental factors that speed up or slow down the government's regulatory responsiveness in the US.

We theorise that the breadth of the congressional statutory delegation of regulatory authority is a key factor driving regulatory timing. Specifically, when Congress expressly directs an agency to promulgate a rule, we hypothesise that agencies issue those rules more quickly. We refer to this as a narrow delegation. Narrow delegations command, often stating that an agency "shall" or "must" issue a rule. We argue that the amount of elapsed time between Congress' demand for a regulation and an agency's promulgation of a regulation will be shorter when Congress provides a narrow delegation. Yet, perhaps the more interesting state of affairs occurs in the opposite scenario, when the statutory authorisation provides a broad delegation of policymaking authority to the bureaucracy. Broad delegations suggest that an agency "may" write a regulation - meaning that Congress allows the agency and autonomy to decide whether or not to write a rule at all. Understood in this way, broad delegations provide decision-making autonomy to agencies. In these cases, we hypothesise that the bureaucracy's internal considerations will be the key drivers of rule timing as opposed to other ex ante, ex post and contemporaneous political factors, which are frequently emphasised in the political science literature.

We use a large dataset that spans four decades to assess our argument, which links the legislature's demand for regulation to the bureaucracy's supply of regulation. In doing so, we provide the first quantitative examination of the timing of agency regulations in response to varying congressional delegations of regulatory authority. We analyse 348 laws delegating rulemaking authority to the US Department of the Interior (DOI) over an almost forty-year time period. These laws are then matched to all draft rules issued by DOI agencies over roughly the same period. We focus on DOI for several reasons, including that Interior's rule-writing agencies hold jurisdiction over an unusually diverse array of critical policy areas (Utley and Mackintosh 1989). We employ flexible parametric models to understand the factors that speed or slow down agency responsiveness to congressional delegations of authority. These techniques, which are innovative in the field (Haeder 2019), allow us to determine the statistical and substantive significance of our theorised drivers across time, while also producing figures that jointly vary predictor variables to better understand how "real world" scenarios affect regulatory timing. 
Overall, we find support for our argument: the breadth of the congressional authorising delegation is strongly associated with agency policy responsiveness, which we conceptualise via regulatory timing. When a statute directs DOI to write a draft rule, the agency generally does so and does so quickly - almost $50 \%$ of such statutes produce a rule within a one-year time period. Moreover, other political factors are also important to rule timing under these narrow delegations, including prestatute congressional hearings. However, for broad delegations of authority, which provide greater discretion to agencies, different patterns emerge. To begin, we find that broad delegations significantly outnumber narrow delegations, and many broad delegations go unanswered, which suggests that the agency may never issue a legally binding rule. Furthermore, when a draft rule is issued, DOI typically takes a long time to do so: two years after the authorisation, less than $20 \%$ of statutes with broad delegations produce a draft agency rule. Our analysis also suggests that under broad delegations, when rules are triggered, they are affected by DOI agency-related considerations, such as resources and workload, as well as statutory deadlines, but not by the factors that tend to dominate scholarship, such as the partisan configuration of government (i.e. a unified or divided government).

This article's theory and findings hold important implications for politics and policy. We know now that the breadth of the original legislative delegation matters to the timing of agency policymaking, and we know that clear congressional demands for regulation are generally met with a quick agency response. In this sense, legislation appears to have a strong hold over regulation. Some observers may find these results reassuring and suggestive of the power that our elected policymakers have over (generally) unelected bureaucrats. However, we also know now that most congressional delegations are of the "broad" variety. And once this type of authority has been transferred, an agency often takes years to issue a draft rule; the timing of which appears often in reaction to its - i.e. the agency's - own considerations. Some observers may see such findings as a distress call in need of a solution, such as legislative sunset provisions attached to all statutory authorisations of rulemaking. For instance, Adler and Walker (2020) see such delegations as normatively troubling - so troubling that they recommend that Congress ought to act to "mitigate the democratic deficits that accompany broad delegations of lawmaking authority to federal agencies and spur more regulatory legislative engagement with federal regulatory policy." However, others may view our article's results as benign, and perhaps indicative of the policymaking flexibility that agency officials need - and Congress willingly provides - to allow the bureaucracy to achieve its mission. Yet, regardless of what one sees, this article adds new evidence to the debate by extending scholarly and practitioner knowledge around one of the premier normative issues in political science: the fraught relationship between legislative delegation and agency policymaking discretion (Lavertu and Weimer 2009).

\section{Theoretical foundations}

At first blush, the demand and supply of agency regulation is hard to reconcile with the US Constitution, which states that Congress must make the laws (USA. Const. 1, 1). This reconciliation is made possible in large part by the fact that 
agencies cannot issue legally binding regulations without an explicit authorisation to do so in enacted law (Posner and Vermeule 2002; Rosenbloom 2018; Adler and Walker 2020). Thus, there must be a statutory basis for agency policymaking. In providing this, Congress can transmit autonomy to government agencies to take advantage of agency expertise and to address issues of policy complexity (Epstein and O'Halloran 1999; McCubbins 1999; Huber and McCarty 2004; Kaufman 2001; Boushey and McGrath 2017). Or, perhaps, as Rourke (1984) concludes, to "shift the burden of finding solutions to administrators, by granting them broad discretionary authority."

\section{Congressional control}

One of the principal concerns for American lawmaking today is that delegation "creates problems for the US Congress when it comes to maintaining control over public policy" (MacDonald 2010). This occurs in part because when Congress devolves authority, it allows the agency to make the first policy move, which if not preempted, generally wins out (Ferejohn and Shipan 1990). As a result, when Congress uses its legislative policymaking power to enable administrative policymaking, there is a risk that agenda setting turns into agenda shifting (Maynard-Moody 1998). Or, as Weingast (2005) puts it, congressional delegation always creates the risk that agency policy outputs will not be responsive to the interests of elected officials and their constituents - a risk that is present even when agency officials earnestly pursue congressional intent (McCubbins 1985). Consequently, understanding agency responsiveness (or lack thereof) after legislative delegation is critical because the "normative debates about the desirability and legitimacy of delegation hinge on the positive question of whether and how Congress can control the decisions of agencies" (Bawn 1997).

The tactics used by Congress to retain political control over delegated policymaking authority are many. The literature, for instance, suggests that Congress utilises agency budgets, political appointments and oversight hearings to influence the US bureaucracy (McCubbins and Schwartz 1984; Wood and Waterman 1991; West 1995; Aberbach 2001; Lewis 2011), and often employs a principal-agent framework to understand the Congress-bureaucracy relationship (Miller 2005; Wood and Waterman 1991). In this article, we focus attention on Congress' use of statutes - and specifically the text of legislative statutes that have been signed into law by the president - to achieve bureaucratic responsiveness. In doing so, we follow Huber et al. (2001), who define statutory control as when "legislators use legislation to influence agency decisions."

Statutory control is an attractive congressional influence tactic for a number of reasons. First, statutes both constrain and enable agency policymaking action. Stated differently, they outline what public agencies can and cannot do. Huber and Shipan (2002), for instance, make the case that when legislators pass more detailed statutes, they are attempting to limit the discretion of agencies. Indeed, it is frequently acknowledged that statutes are used to restrict and to structure how an agency will make policy choices - often through the use of administrative procedures (McCubbins 1985; McCubbins et al. 1987, 1989; Epstein and O'Halloran 1999; Tsebelis 2002; Moffitt 2014). Yet, statutes are a dual-edged sword as they do 
not just constrain and limit behaviour, they also enable agency policymaking in the first place, and therefore they provide agencies the necessary legitimation and autonomy to issue policy decisions (Hill and Lynn Jr 2015).

Second, statutes are legally binding, and thus agencies must largely follow the dictates of statutes. After all, ignoring a congressional statutory command differs from, for example, ignoring the commands of a member of Congress made during a committee hearing, in a press release, or in a letter to an agency. While such actions may threaten, statutes hold the force of law and may be litigated. As a result, "when faced with lawsuits for failing to perform nondiscretionary duties, agencies tend to settle because their liability is clear" (Johnson 2013).

Third, statutes are durable (Shepsle 1992). The coalitional politics necessary to pass a statute, which is signed into law by the president, ensure most statutes' permanency. In other words, statutes regularly remain in effect for a long period of time and are difficult to reverse or revise. Indeed, given that other oversight activities are often "conditional on the ability of lawmakers to enact new laws" (MacDonald 2010; see also Shipan 2004), the durability of statutes arguably elevates statutory control over other types of congressional control tactics.

\section{The timing of agency action}

What is a legislature "controlling" when it uses a statute to affect agency decision making? Within the context of a statutory delegation of policymaking authority, Congress is setting the agency's agenda, suggesting what can, and at times what should, be the agency's policy priorities and actions (West and Raso 2013; Kerwin and Furlong 2018). This agenda setting role raises a number of questions, of which we are particularly interested in when agencies respond to legislative agenda setting, as well as why. Thus, our focus acknowledges that agencies make policy choices when they make timing choices, such as the decision to speed up or slow down agency action (Ando 1999; Carpenter 2002, 2004; Potter 2019). It also acknowledges that the timing of agency regulations, in particular, is an important political act (Revesz and Davis Noll 2019). In the end, "agencies have significant time discretion in their operations and decisions"; yet, surprisingly, this type of timing discretion has not been "heavily studied" by scholars, researchers or practitioners (Carpenter et al. 2012).

Most observers suggest that if a shorter duration of time elapses between the Congress' demand for agency action and the agency's supply of that action, then this is indicative of greater agency responsiveness (Lowande 2019). And, while shorter may not always be better, reasonable people will likely agree that, when Congress tells an agency to issue a draft rule and it takes several decades for the agency to do so, it does not indicate particularly responsive behaviour. This general assumption is also well reflected in the literature, which, when it has focused on regulatory timing, has tended to emphasise the ability of legislatures to insert deadlines into some statutes to speed up the responsiveness of agency policymaking (Carpenter 2004; Lavertu and Yackee 2012; Carpenter et al. 2012). As a result, while the exact normative threshold for what constitutes "responsiveness" may be difficult to pin down, it is clear that, at a minimum, the idea of responsiveness has elements of timing built in. 
Bertelli and Doherty (2019) offer an important innovation by focusing on calendar and political time. In their analysis of congressionally imposed deadlines, they find that while federal government agencies frequently miss rule-specific date deadlines in congressional statutes, agencies often promulgate these same rules before the next major political election. This critical finding helps to reorient the literature by emphasising the need to consider political time as part of an agency's calculus on rule promulgation. Time is also built into what Freeman and Spence (2014) call the problem of the Two Congresses. This refers to the fact that the Congress that originally enacts a statute delegating policymaking authority to an agency is generally not the same - in terms of its make-up or preferences - as the Congress in office when an agency ultimately issues a draft regulation using its delegated rulemaking authority. As Yaver (2015) explains, "[M]any significant laws being implemented today were passed several Congresses ago, [and] the policy preferences of these Congresses may be highly divergent, leading to potentially substantial coalition drift." This problem is created in part by the fact that the Administrative Procedure Act of 1946, which requires agencies to take public feedback on draft regulations before issuing legally binding rules, automatically builds some delay into the agency policymaking process (West 1995; Rosenbloom 2018). Nevertheless, when time elapses between a congressional delegation and the agency's use of this delegated authority to make policy, it creates a time consistency problem that holds implications for our understanding of bureaucratic responsiveness to Congress (Shepsle 1992). Or, as Adler and Walker (2020) put it, "In this respect, the lag between delegation and regulation may create a particularly concerning democratic deficit." When taken together, this suggests a need to unpack and to measure the dynamic nature of agency responsiveness to congressional calls for agency regulation.

\section{Argument}

We seek to understand when legislation triggers regulation, and in so doing, to better explicate the link between delegation and discretion as it unfolds over time. To accomplish this, we drill down on the relationship between legislative statutes that delegate new rulemaking authority to public agencies and the timing of agency regulations that employ this delegated discretion. While the delegation literature is vast, we throw new light on what West and Raso (2013) write "has received little attention" from scholars to the point that it has been "almost completely ignored": the role of Congress in directing future agency policymaking.

We begin with the uncontroversial claim that not all instances of delegation passed by legislatures are the same. In making this distinction, we suggest the importance of what Crawford and Ostrom (1995) label the "grammar" of political institutions. We theorise that the grammar, if you will, used in the statutory delegation of rulemaking authority is critical to our understanding of agency responsiveness because it - in just a word or two - succinctly sets up the rules of the game. In short, it establishes the broad parameters of what the agency can and cannot do. Of particular interest to us is the weight that Crawford and Ostrom (1995) place on the modal operators used in grammar's deontic logic - especially shall and must as compared to may. As Crawford and Ostrom (1995) theorise, these operators are key 
to understanding the relationships set forth in political texts because these are the words that define what is obligatory and what is permitted and distinguish between what are "prescriptive and nonprescriptive statements."

Congress habitually uses these deontic logic operators in its statutes to delegate regulatory authority to federal agencies (see e.g. Copeland 2010), and we theorise that these operators are pivotal to understanding when, as well as why, agencies issue regulations in response to new delegated authority. Specifically, we suggest a distinction between statutes that provide a narrow delegation of decision-making autonomy from those that provide a broad delegation. Importantly, we suggest that this statutory distinction - between narrow and broad delegation regimes - is a parsimonious way to understand the scope of the original legislative act, and we expect it to hold policy effects for the timing of agency regulations.

Narrow delegations, we argue, are those where Congress tells an agency that it shall or must issue a regulation in response to new statutory authority. We see these as "narrow" in the sense that the level of discretion provided to the agency is circumscribed: issuing a rule is nearly obligatory. Of course, as Crawford and Ostrom (1995) highlight, this type of mandatory language begs the question, "or else?" In this case, the sanctions are relatively clear for agency noncompliance. That is, one can expect that if an agency fails to issue a regulation when commanded by statute to do so - or is particularly delayed in doing so - affected parties will sue the agency and force it to carry out its legal obligation (Johnson 2013). Or, as West and Raso (2013) put it, "The primary way in which courts can shape the bureaucracy's policy-making agenda is by enforcing statutes that require agencies to issue rules." Moreover, an agency can reliably believe that sanctions will be forthcoming from Congress, if not from the courts. After all, Congress presumably has an interest in assuring that government agencies follow its clear statutory commands and therefore has an increased likelihood of using tools to punish agencies for noncompliance, such as budgets, hearings and appointments.

Broad delegations are those where Congress tells an agency that it "may" issue a regulation in response to a new grant of policymaking authority. Crawford and Ostrom (1995) call this deontic logic operator "perplexing," in the sense that it prescribes behaviour but does not specifically require it; that is, it permits action, while essentially suggesting that the agency may use its collective judgement as to if and when to pursue it. Walters (2019) also suggests that "may" grants of rulemaking authority are complicated because they provide little by way of concrete instruction from Congress. We see this form of statutory control - assuming "control" is the appropriate word - as providing a quintessential illustration of devolved discretion to agencies.

Hypothesis 1: Our key hypothesis that the amount of elapsed time between Congress' demand for a regulation and an agency's promulgation of that regulation will be shorter when Congress provides a narrow delegation than when it provides a broad delegation. As McCubbins (1999) writes, "Federal agencies are creatures of Congress and are subject to the strictures of their creator," and we also know that the "force of new legislation makes it a powerful tool" (Weingast 2005). Thus, when Congress passes an action-forcing statute, such as a statute with a narrow delegation, we argue that there will be a relatively quick regulatory response from the agency. In many ways, this pattern matches what scholars have long suspected, which is that the 
regulatory agenda is marked by punctuations of rules that closely follow new legislation, which calls for regulation action (Golden 2003).

Hypothesis 2: We also hypothesize that when a narrow delegation is paired with other clear signals from Congress regarding its interest in a statute, it will work to further speed up agency action. We situate this hypothesis in the literature suggesting that agencies respond to signals sent by their political principals (Wood and Waterman 1991; Shipan 2004; Huber 2007). We expect agency action to be more focused on regulations where there has been a clear expression of interest from Congress (Yackee and Yackee 2010).

Hypothesis 3: Finally, we hypothesize that the bureaucracy's internal considerations such as its regulatory experience and contemporaneous resources - will be key drivers of rule timing when a statute provides a broad delegation of policymaking authority to the bureaucracy. After all, we know that, from Sunstein and Vermeule's (2014) work, the number of rules most agencies could issue at any point in time is often high, and consequently, agencies must continually prioritise the promulgation of some agency rules and delay work on others. Thus, when provided the flexibility and autonomy of a "may" delegation of authority, we expect this type of prioritisation process will be affected in part by workload factors contemporaneously impacting an agency.

To be clear, we are not suggesting that Congress' choice between narrow and broad delegation language is a procedural one; the literature is replete with examples of how procedural requirements may influence agency decisionmaking (e.g. McCubbins et al. 1987, 1989; Balla 1998; Epstein and O'Halloran 1999). Nor are we suggesting that this choice is akin to the overall level of detail provided in the statute (Huber and Shipan 2002). Instead, we are arguing that the narrow and broad delegation distinction is a fundamental, substantive and parsimonious statutory construction choice that is routinely and purposively used by Congress to affect agency behaviour. Given this, we are interested in the downstream policy consequences of this choice, as well as any commensurate implications for bureaucratic policy responsiveness.

\section{Testing the argument}

We assess the argument by focusing on the dynamic empirical relationship between the policymaking authority centred in the legislative branch and the policymaking actions of the executive branch. More specifically, we use a large dataset that spans four decades (Haeder and Yackee 2021), which links the legislature's demand for regulation to the bureaucracy's supply of regulation. In doing so, we assess the article's three hypotheses regarding agency policy responsiveness.

\section{Data}

Our analysis is based on information from two previously collected datasets, which we bring together and significantly expand upon to produce innovative, new 
research regarding the timing of draft agency rules. The main dataset focuses on all statutory grants of regulatory policymaking power to DOI from 1950 to 1987. The focus on DOI provides several benefits to our assessments. In particular, DOI and its many subagencies have a broad regulatory mandate - from mining rights to endangered species to tribal health care (Utley and Mackintosh 1989) which assists in the generalisability of the results. ${ }^{1}$ Moreover, this time period allows us to undertake an empirical examination of the modern administrative state immediately after the implementation of the pivotal Administrative Procedure Act of 1946 (APA) (Rosenbloom 2000). The APA is a quasi-constitutional statute that, even today, sets the standards for all federal agency rulemaking and thus remains a fresh topic of continued scholarly debate (West 1995; Kerwin and Furlong 2018; Rosenbloom 2018).

Both datasets were originally compiled by Yackee and Yackee (2016). However, as we highlight below, we also supplement these datasets significantly with our own original data collection efforts. The first dataset contains information on all 348 statutes passed by Congress that directed new rulemaking authority to DOI from 1950 to 1987. Using a set of coding rules, they identified all rulemaking authority delegations to DOI and its agencies from the text of public laws. Regarding these statutes' general distribution, they are distributed with consistency across time, and we do not see major changes across the period of observation. The second dataset is based on information collected on all Notice of Proposed Rulemakings (also called "NPRMs" or "draft rules") issued by DOI from 1950 to 1990. They used trained coders to identify the relevant NPRMs in the Federal Register. These coders discerned the statutory authority citation(s) for the regulation, which allows for a matching of the 348 statutes in our study to the first NPRM issued by DOI that employs that statutory authority.

\section{Variables}

We create the article's dependent variable of interest, Time to Draft Rule, which is a count of the number of days between a congressional statute delegating new rulemaking authority to DOI and the first draft rule issued by DOI using that delegated authority. We focus on the NPRM because it is the first major milestone indicating agency regulatory policy responsiveness. Our main explanatory variable, Narrow Delegation, is dichotomous and measures whether a delegation grant is narrow (coded as a 1) or broad (coded as a 0 ). ${ }^{2}$ Narrow grants are those that instruct

\footnotetext{
${ }^{1}$ DOI agencies in this dataset are the Bureau of Indian Affairs (BIA), the Bureau of Land Management (BLM), the Fish and Wildlife Service (FWS), the National Park Service (NPS), the Office of Oil and Gas (OOG), the Oil Import Administration (OIA), the Office of the Secretary (OOS), the Bureau of Mines (BOM), the Bureau of Reclamation (BOR) the US Geological Survey (GES), the Heritage Conservation and Recreation Service (HCR), the Minerals Management Service (MMS), the Office of Minerals Exploration (OME), the Office of Surface Mining, Reclamation, and Enforcement (OSM), the Office of Saline Water (OSW), the Federal Water Pollution Control Administration (WPC) and the Mining Enforcement and Safety Administration (MES).

${ }^{2}$ This is a statute-based measure. According to the coding rules, if a statute had more than one regulatory delegation and mixed the narrow and broad authority types, then the statute was coded as providing narrow authority.
} 
Table 1. Descriptive statistics for the independent variables

\begin{tabular}{|c|c|c|c|c|}
\hline Variables & Mean & SD & Min & Max \\
\hline \multicolumn{5}{|l|}{ Congress ex ante } \\
\hline Narrow delegation & 0.08 & 0.27 & 0.00 & 1.00 \\
\hline Deadline & 0.01 & 0.10 & 0.00 & 1.00 \\
\hline Hearings ex ante & 4.49 & 4.88 & 0.00 & 95.00 \\
\hline Statute complexity & 17.08 & 70.39 & 2.00 & 819.00 \\
\hline \multicolumn{5}{|l|}{ Congress ex post } \\
\hline Hearings ex post & 21.70 & 15.12 & 0.00 & 86.00 \\
\hline House lead remaining" & 0.25 & 0.43 & 0.00 & 1.00 \\
\hline Senate lead remaining" & 0.19 & 0.39 & 0.00 & 1.00 \\
\hline Partisan coalition ${ }^{\#}$ & 0.48 & 0.50 & 0.00 & 1.00 \\
\hline \multicolumn{5}{|l|}{ Department of the interior } \\
\hline Workload accumulation ${ }^{\#}$ & 11.96 & 6.30 & 0.00 & 22.00 \\
\hline DOI employees\# & 7526 & 1000 & 3933 & 9038 \\
\hline DOI NPRMs ${ }^{\#}$ & 88.55 & 28.71 & 9.00 & 136.00 \\
\hline \multicolumn{5}{|l|}{ Environmental } \\
\hline Statute significant & 9.70 & 42.75 & 0.00 & 590.00 \\
\hline Unified government & 0.60 & 0.49 & 0.00 & 1.00 \\
\hline Time to presidential Election" & 643.75 & 391.76 & 3.00 & 1455.00 \\
\hline Initial administration ${ }^{\#}$ & 0.20 & 0.40 & 0.00 & 1.00 \\
\hline
\end{tabular}

\#indicates time variant variable.

DOI that it "must" or "shall" issue a regulation. Broad grants are more ambiguous and often include the word "may" in the statutory delegation (Walters 2019). ${ }^{3}$ Overall, there are 69 narrow grants and 279 broad delegation grants in the data. That is, broad grants of delegated authority are four times more common than narrow grants. Descriptive statistics for this and other predictor variables are presented in Table 1.

We also include a number of additional independent variables in our analyses, which we group together into four main clusters: congressional ex ante, congressional ex post, DOI and environmental variables. With regard to congressional ex ante variables, we first account for whether a statute includes a Deadline. Deadlines are inserted in some statutes to speed up the agency's regulatory responsiveness and thus may serve to reduce the time to NPRM. Our models also incorporate a count of the congressional Hearings Ex Ante, which are held on the authorising statute but prior to its passage. A larger number of ex ante hearings may signal greater evidence of congressional interest to the agencies. Finally, more complex statutes may require more time to implement (Statute Complexity). We account for this possibility by including the number of statute pages.

Congressional attention after the passage of a bill (i.e. ex post oversight) may also hold influence over the timing of draft agency regulations. Similar to congressional hearings prior to a statute's passage, a hearing held on a statute after its passage into law may signal continued congressional attention to an agency. We thus include a count for the number of Hearings Ex Post. The lead sponsors of the statute from both chambers may also play an important role, and we account for them still being

\footnotetext{
${ }^{3}$ We provide a list of common delegation operators in Appendix A.
} 
in Congress at any point across analysis time with two indicator variables. ${ }^{4}$ Lasting congressional coalitions may influence regulatory timing as well. Therefore, we measure whether the Partisan Coalition in place when the statute was passed remains in power. This variable thus taps changes to the majoritarian make-up of the partisan coalition in Congress across time. It scores a 1 as long as the original majoritarian circumstances in Congress remain the same as at the statute's passage and is coded a 0 thereafter.

A large department like DOI is tasked with a multitude of duties at any given point in time, and the ability of the department to accomplish these tasks is affected by its resources and its workload. Rulemaking is no exception. Thus, we include the number of DOI Employees in Washington, DC, the hub of DOI rulemaking, in our models. More employees may augment the department's ability to respond to a new delegation of authority. At the same time, the Workload Accumulated, which we calculated as the accumulated number of statutes requiring a regulation that have not received one, may have the opposite effect of slowing down an agency's progress. Finally, agencies that issue more rules may have more experience with rulemaking and more systems in place and thus react quicker to new congressional authorisations. Consequently, we include the annual number of DOI NPRMs in our analyses.

Environmental factors may also exert influence on the time from statute to NPRM. For one, important statutes may draw more attention from the agency and thus encourage quicker regulatory activity (called Statute Significant). Hence, we include the number of scholarly citations to a particular statute, which suggests its relative consequence. ${ }^{5}$ We also create Initial Administration, which is coded a 1 as long as the party of the president at the statute's passage remains the same and scores a 0 thereafter. Moreover, we also interact this variable with the previously described Partisan Coalition. In order to properly account for political time, we develop and include a measure, Time to Presidential Election, which is the time in days from the authorisation statute to the first presidential election after statute passage. ${ }^{6}$ Finally, a number of studies have focused on the role that unified or divided government plays in delegation and discretion (Epstein and O'Halloran 1999; Tsebelis 2002; Farhang and Yaver 2016). Thus, we include an indicator for Unified Government at passage.

\section{Methods}

We employ event history methods that are innovative within political science. Specifically, we rely on Royston-Parmar models, which are commonly used in the medical literature. In many respects, Royston-Parmar models (Royston 2001; Royston and Parmar 2002; Lambert and Royston 2009; Royston and Lambert 2011; Haeder 2019) provide a sound middle ground between the semiparametric Cox model and a fully parameterised approach. One advantage is Royston-Parmar models

\footnotetext{
${ }^{4}$ We generated all of the congressional ex post variables from CQ Legislative Insight and CQ Congressional.

${ }^{5}$ The source is HeinOnline's scholar check feature.

${ }^{6}$ Additionally, we replicated all models by replacing this variable with a construct capturing the Time to the Next General Election and returned analogous results.
} 
improve on the noisy hazard and survival functions of the Cox models, as well as the Kaplan-Meier and Nelson-Aalen estimators, which allows for easier interpretation. Moreover, Royston-Parmar models estimate a baseline hazard and thus allow us to utilise information contained in the baseline across the observation period. Thus, we can evaluate absolute as well as relative risk. Royston-Parmar models also provide added flexibility over parametric models. This flexibility allows complex hazard functions and the estimation of classes of models beyond traditional regression approaches. Conveniently, the various scales reduce to Weibull, loglogistic and lognormal models when warranted. Moreover, unlike many parametric models, they are not monotonic in their hazard functions and may have more than one turning point. Another advantage is that Royston-Parmar models are also not restricted to the proportional hazard assumption; they are estimated by full maximum likelihood, and Akaike's Information Criteria (AIC) and Bayesian Information Criterion (BIC) can be used for comparisons.

Importantly, Royston-Parmar models allow us to study the changing hazard of rule promulgation over time - which may vary considerably across analysis time. After all, some variables may be quite meaningful immediately after statute passage, while others may materialise only as significant after some time has passed. Given this critical feature of Royston-Parmar models, the data relationships are best shown in graphs that allow the researchers to display the changing hazard by plotting them over time. Consequently, we use several graphs in the article to display our results. As the reader will see, the graphs allow for easy discernment of both statistical and substantive significance and can be created while strategically varying other covariates to mimic "real world" scenarios. Positive coefficients suggest that a predictor variable is associated with increased regulatory responsiveness - wherein greater responsiveness is operationalised as a shorter amount of elapsed time between Congress' authorisation of an agency action and the agency's supply of that action. Negative coefficients suggest slower rule production. We will note here that the coefficients that we present in the article provide information regarding the overall statistical significance of the predictor variables. However, some variables may only be significant early in a rule's life course, while others may become significant only late. Still others may be displayed in the table as, on average, statistically insignificant but may reach the significance threshold at certain points across analysis time. Given this, we also present our key findings in graphical form, which allows the reader to readily appreciate these patterns. Statistical significance is established at standard discipline levels.

\section{Results}

\section{Hypothesis 1: Variation in delegating statutes}

We provide the first sophisticated quantitative examination of the timing of agency regulations in response to varying congressional delegations of regulatory authority. Our key results are displayed in Figures 1 and 2 and Table 2. In our first and key hypothesis, we theorised that the breadth of the statutory delegation of policymaking authority in the original enabling legislation conditions the timing of agency regulatory responsiveness. In particular, we suggest that a parsimonious way to understand agency responsiveness to legislative policymaking delegation is to 


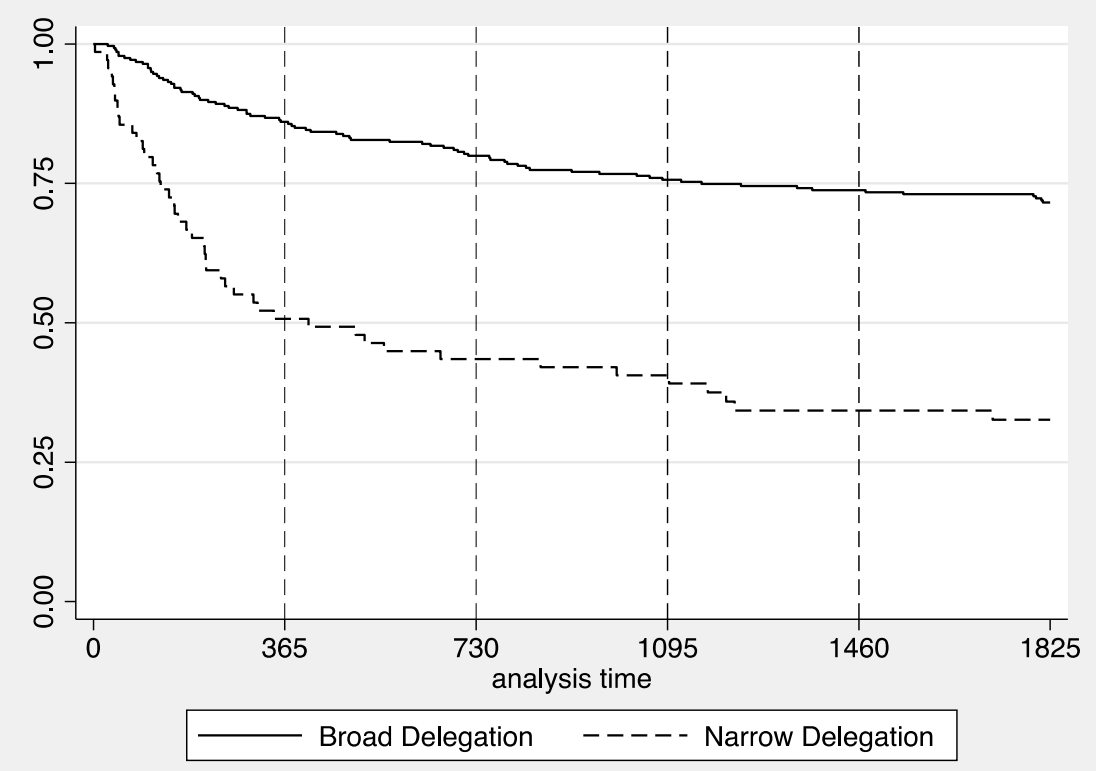

Figure 1. Kaplan-Meier survival estimates: narrow versus broad delegation.

Note: Kaplan-Meier estimates are shown for the first 1,815 days for illustrative purposes. Results are statistically different from each other at conventional levels. Confidence bounds are omitted for clarity.

concentrate on the modal operators - such as must and may - found in delegating statutes.

We find strong support for Hypothesis 1 in Figure 1. Figure 1 uses Kaplan-Meier nonparametric estimators to assess the promulgation of NPRMs across our two key conditions of interest: narrow and broad delegations. As hypothesised, statutes with narrow delegations appear to trigger agency rules much more quickly than statutes with broad delegations. The differences are significant at conventional levels. Overall, the dashed line is initially much steeper than the solid line; this suggests that agency officials provide more attention to required regulatory delegations in the months and years immediately following this type of delegation statute than to rules citing more permissive statutory authority. In looking at the one-year mark, about $50 \%$ of statutes with narrow delegations have produced a regulation, while substantively less than $20 \%$ of those with broad delegations have done so. ${ }^{7}$ At the four-year mark, the number increases to $60 \%$ for the former and remains around $25 \%$ for the latter. Additionally, as implied by our theoretical argument, across the full survival estimate, the dashed line is consistently and substantively below the solid line. This result implies that across analysis time, the risk of rule promulgation is higher for rules with narrow delegations compared to those with broad delegations.

${ }^{7}$ For ease of presentation, we only show the first five years across all article figures. 
Table 2. Time passage from legislation to regulation

\begin{tabular}{|c|c|c|c|c|}
\hline & & (1) & $(2)$ & (3) \\
\hline & Variables & $\begin{array}{c}\text { All } \\
\text { statutes }\end{array}$ & $\begin{array}{c}\text { Narrow } \\
\text { delegations }\end{array}$ & $\begin{array}{c}\text { Broad } \\
\text { delegations }\end{array}$ \\
\hline \multirow[t]{4}{*}{ Congress ex ante } & Narrow delegation & $\begin{array}{l}1.014^{\star \star \star} \\
(0.000)\end{array}$ & & \\
\hline & Deadline & $\begin{array}{l}1.156^{\star \star \star} \\
(0.007)\end{array}$ & $\begin{array}{c}0.532 \\
(0.160)\end{array}$ & $\begin{array}{l}1.921^{\star \star \star} \\
(0.008)\end{array}$ \\
\hline & Hearings ex ante & $\begin{array}{c}0.012 \\
(0.215)\end{array}$ & $\begin{array}{c}0.017^{\star} \\
(0.062)\end{array}$ & $\begin{array}{c}0.007 \\
(0.740)\end{array}$ \\
\hline & Statute complexity & $\begin{array}{c}0.001 \\
(0.543)\end{array}$ & $\begin{array}{l}0.003^{*} \\
(0.085)\end{array}$ & $\begin{array}{c}-0.001 \\
(0.552)\end{array}$ \\
\hline \multirow[t]{4}{*}{ Congress ex post } & Hearings ex post & $\begin{array}{r}-0.008 \\
(0.292)\end{array}$ & $\begin{array}{r}-0.002 \\
(0.867)\end{array}$ & $\begin{array}{r}-0.011 \\
(0.176)\end{array}$ \\
\hline & House lead remaining ${ }^{\#}$ & $\begin{array}{r}-0.086 \\
(0.733)\end{array}$ & $\begin{array}{l}1.231^{\star \star \star} \\
(0.005)\end{array}$ & $\begin{array}{r}-0.327 \\
(0.266)\end{array}$ \\
\hline & Senate lead remaining ${ }^{\#}$ & $\begin{array}{c}0.208 \\
(0.386)\end{array}$ & $\begin{array}{l}-1.089^{\star \star} \\
(0.015)\end{array}$ & $\begin{array}{c}0.360 \\
(0.195)\end{array}$ \\
\hline & Partisan coalition ${ }^{\#}$ & $\begin{array}{c}0.233 \\
(0.616)\end{array}$ & $\begin{array}{r}-0.691 \\
(0.374)\end{array}$ & $\begin{array}{c}0.486 \\
(0.357)\end{array}$ \\
\hline \multirow[t]{3}{*}{$\begin{array}{l}\text { Department of the } \\
\text { interior }\end{array}$} & Workload accumulation" & $\begin{array}{l}-0.089^{\star \star} \\
(0.019)\end{array}$ & $\begin{array}{l}-0.254^{\star \star \star} \\
(0.000)\end{array}$ & $\begin{array}{r}-0.045 \\
(0.298)\end{array}$ \\
\hline & DOI employees ${ }^{\#}$ & $\begin{array}{c}0.000 \\
(0.478)\end{array}$ & $\begin{array}{l}0.001^{\star \star \star} \\
(0.004)\end{array}$ & $\begin{array}{r}-0.000 \\
(0.846)\end{array}$ \\
\hline & DOI NPRMs" & $\begin{array}{l}0.021^{\star \star \star} \\
(0.000)\end{array}$ & $\begin{array}{l}0.016^{\star \star} \\
(0.044)\end{array}$ & $\begin{array}{l}0.021^{\star \star \star} \\
(0.001)\end{array}$ \\
\hline \multirow[t]{14}{*}{ Environmental } & Statute significant & $\begin{array}{l}0.007^{\star \star \star} \\
(0.000)\end{array}$ & $\begin{array}{l}0.004^{\star \star \star} \\
(0.006)\end{array}$ & $\begin{array}{l}0.009^{\star \star \star} \\
(0.001)\end{array}$ \\
\hline & Unified Government & $\begin{array}{r}-0.205 \\
(0.420)\end{array}$ & $\begin{array}{c}0.042 \\
(0.920)\end{array}$ & $\begin{array}{r}-0.225 \\
(0.443)\end{array}$ \\
\hline & Time to presidential election ${ }^{\#}$ & $\begin{array}{r}-0.000^{*} \\
(0.077)\end{array}$ & $\begin{array}{l}0.001^{*} \\
(0.056)\end{array}$ & $\begin{array}{l}-0.001^{\star \star} \\
(0.029)\end{array}$ \\
\hline & Initial administration" & $\begin{array}{r}-0.093 \\
(0.880)\end{array}$ & $\begin{array}{c}0.361 \\
(0.740)\end{array}$ & $\begin{array}{r}-0.086 \\
(0.905)\end{array}$ \\
\hline & $\begin{array}{l}\text { Initial administration } \times \text { partisam } \\
\text { coalition }^{\#}\end{array}$ & 0.197 & 0.669 & -0.021 \\
\hline & & $(0.758)$ & $(0.551)$ & $(0.978)$ \\
\hline & Constant & $\begin{array}{l}-2.677^{\star \star} \\
(0.014)\end{array}$ & $\begin{array}{l}-8.068^{\star \star \star} \\
(0.001)\end{array}$ & $\begin{array}{r}-1.578 \\
(0.210)\end{array}$ \\
\hline & Number of statutes & 348 & 69 & 279 \\
\hline & Failures & 160 & 48 & 112 \\
\hline & Days at risk & $1,730,472$ & 135,033 & $1,595,439$ \\
\hline & Model & Odds & Hazard & Odds \\
\hline & Degrees of freedom & 3 & 3 & 3 \\
\hline & $\mathrm{BIC}$ & 1005 & 246 & 787 \\
\hline & Observations & 130,672 & 10,464 & 120,208 \\
\hline
\end{tabular}

All models are flexible parametric survival models; $p$ values in parentheses; \#indicates time variant variable; ${ }^{* \star *} p<0.01$, ${ }^{\star \star} \mathrm{p}<0.05,{ }^{\star} \mathrm{p}<0.1$.

We find further support for Hypothesis 1 in Table 2, Model 1 (and the corresponding Figures $2 \mathrm{a}$ and $2 \mathrm{~b}$ ), which provides the fully specified event history model predicting regulatory timing using the DOI data with all covariates described above. It allows us to assess whether or not the breadth of the statutory delegation distinction, which stands out in the Kaplan-Meier estimates, remains a critical factor 


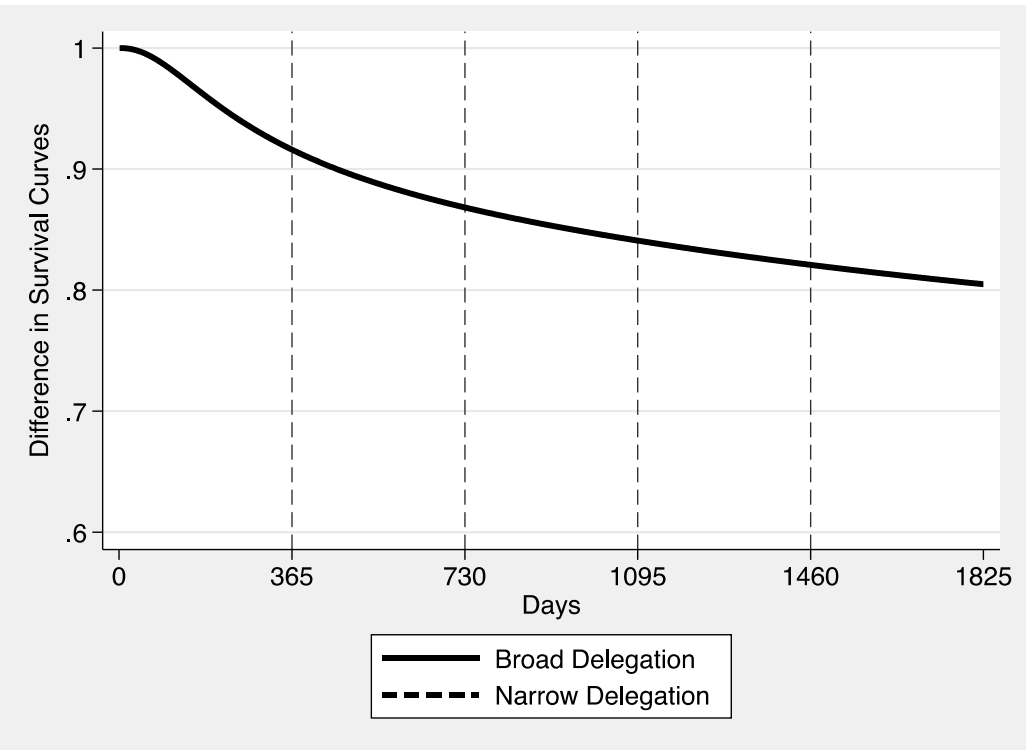

Figure 2a. Survival curves for broad and narrow delegation in model 1.

Note: Narrow Delegation is varied from 0 to 1 . All other variables are set at their mean or mode.

once a variety of other predictor variables are included in the specification. Our expectation is that a Narrow Delegation will trigger a draft agency regulation much more quickly than a discretionary statute. And we see suggestive evidence of this pattern: the coefficient for Narrow Delegation is positive and statistically significant. This indicates that Congress may increase regulatory responsiveness when it requires an agency to write a rule, as opposed to permitting it to write a rule. To further explore the effect of Narrow Delegation, we plot the survival curves across analysis time for broad (solid line) and narrow delegation (dashed line), while setting all other variables to their mean or modal values, as appropriate in Figure 2a. Figure $2 \mathrm{~b}$ then presents the difference between these two survival curves, which is the measure of interest in testing the hypothesis and assesses whether that difference is statistically different from zero. Specifically, the solid dark black line presents the difference between the survival curves for the two values of the variable whereas the dotted lines provide the $90 \%$ confidence interval. The figure's initial steep upward trend line implies that delegating statutes containing a "shall" or "must" requirement, as opposed to a "may" (or similar) delegation, trigger DOI action at a much faster pace over the first years of analysis time. After that, the line flattens out but nonetheless continues to increase. In short, we find consistent support for our main argument that the type of delegation has significant and substantial effects on the timing of NPRMs.

\section{Hypothesis 2: A focus on narrow delegation}

As outlined above, we also hypothesised that when a narrow delegation is paired with other clear signals from Congress regarding its interest in a statute, it will work to further speed up agency action. We rely on the Model 2 specification to test this 


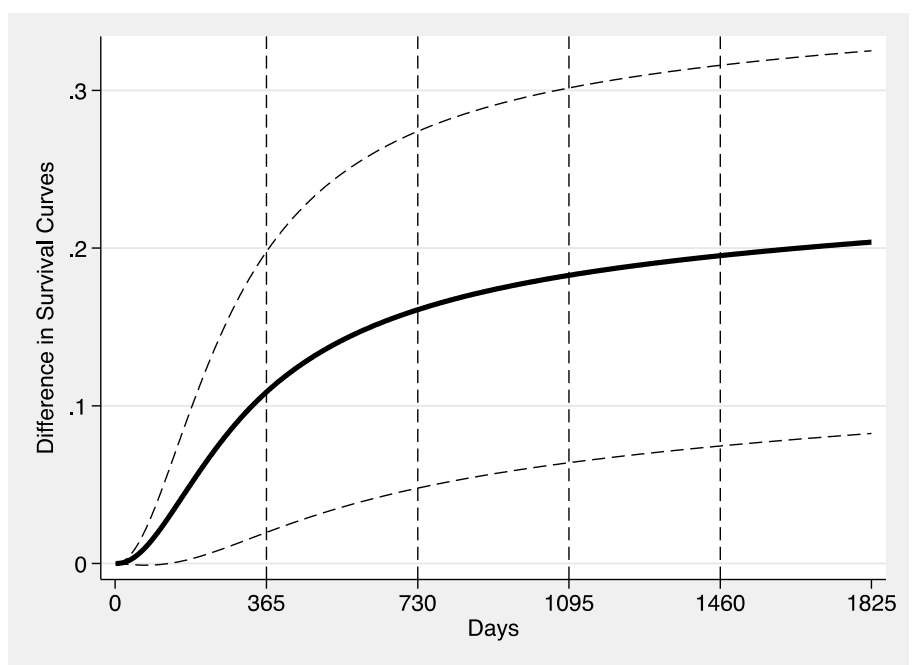

Figure 2b. Difference in survival curves for narrow delegation in model 1.

Note: Narrow Delegation is varied from 0 to 1 . All other variables are set at their mean or mode.

hypothesis. As we mentioned earlier, one of the advantages of the graphical display and interpretation this modelling technique allows is that we can use it to model scenarios in the data. For instance, using the Model 2 specification that is for narrow delegations, we can plot the risk of rule promulgation when all the Congress ex ante variables are turned "on," which we do in Figure 3. By "on", we mean a scenario where all of the variables work to speed up draft rule promulgation. ${ }^{8}$ We can then compare this Congress ex ante scenario to the baseline scenario for Narrow Delegation, which is a scenario where all other variables are set to their mean and modal values. As described above, we can then compare these two survival curves and determine whether the difference between the two curves is statistically different from zero. We can also repeat this analysis by comparing the baseline to the scenario where all the Congress ex post variables favour swift promulgation, again assessing whether the difference between the two curves is statistically different from zero. Finally, we can combine the ex ante and ex post scenarios and compare them to the baseline scenario.

We rely on the display of differences in survival curves, which are presented in Figure 3, to assess our hypothesis. In Figure 3, the Congress ex ante scenario (versus the Narrow Delegation baseline scenario) is displayed by the solid line, the Congress ex post scenario (versus the Narrow Delegation baseline scenario) by the dashed line and the combined scenario (versus the Narrow Delegation baseline scenario) by the dotted line. All three scenarios are statistically different at the $90 \%$ level from the baseline (except for a period immediately after passage of the statute) providing solid support for Hypothesis 2. Legislation with a narrow delegation can work in

\footnotetext{
${ }^{8}$ In this scenario, for instance, the statute had a deadline, a large number of hearings were held before the statute's passage and the statute was highly complex. All other model variables are set to their mean or modal values.
} 


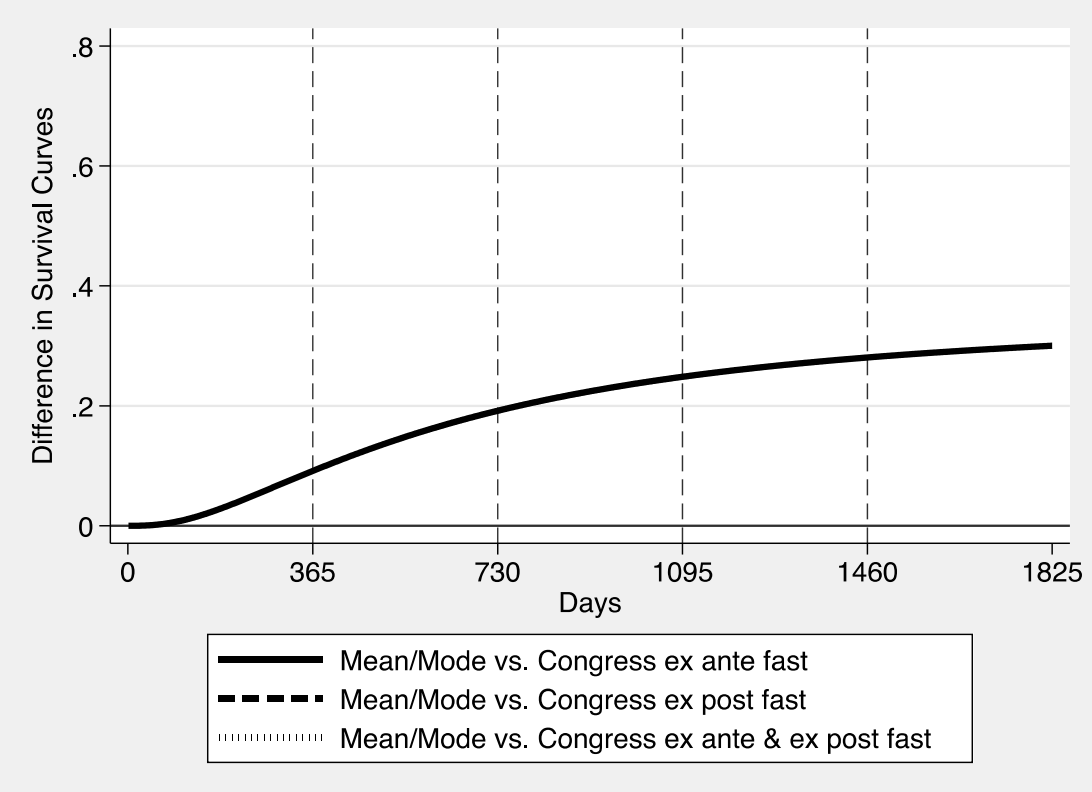

Figure 3. Differences in survival curves comparing baseline to various scenarios for model 2. Note: Confidence intervals are omitted. Scenarios are statistically different from baseline except for a period after the statute is passed. For all scenarios, we varied the values of the respective variable between large and small values while holding all other variables at their mean or modal value.

concert with ex ante and ex post congressional actions to accelerate the timing of regulations. Indeed, under the high ex ante and ex post scenario, the probability of promulgation increases by roughly 0.1 at the one-year mark and continues to increase thereafter. Consequently, while both ex ante and ex post factors individually speed up promulgation, the combined effect is substantial: the difference in probabilities reaches 0.3 at the one-year mark for the combined scenario and continues to grow swiftly for about another two years before flattening out.

\section{Hypothesis 3: A focus on broad delegation}

Finally, we hypothesised that the bureaucracy's internal considerations - such as its regulatory experience and contemporaneous resources - will be key drivers of rule timing when a statute provides a broad delegation of policymaking authority to the bureaucracy. We rely on Model 3, which focuses on statutes with broad delegations, to test this hypothesis. To assess this argument, we study the scenario when all the DOI variables are turned "on" (i.e. set to speed up a draft rule's issuance) while the other model variables are set to their mean or modal values, and then we compare the survival curve to the baseline model. The results are shown graphically in Figure 4 . The key relationship is displayed as a solid line. As expected, the difference between the survival curves is positive, indicating that with the DOI variables turned "on", rules are issued faster. The difference in the survival curves 


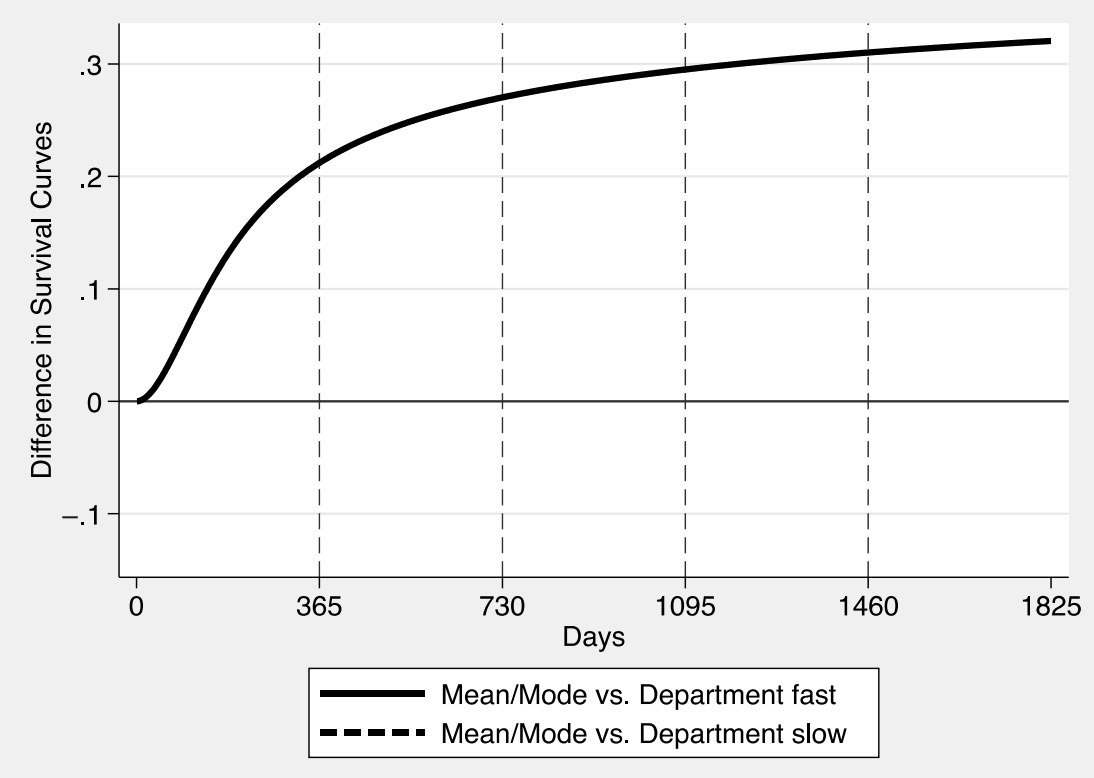

Figure 4. Survival curves comparing baseline to department fast and department slow for model 3. Note: Confidence intervals are omitted. Scenario "Department slow" is statistically different from the Mean/Mode scenario except for a very brief period early on.

reaches conventional levels of statistical significance (except for a period immediately after passage of the statute). We also tested the opposite scenario, that is we compared the circumstances where all DOI variables are turned "off" (i.e. set to slow down a draft rule's issuance). The differences in survival curves (the dashed line in Figure 4) are once more statistically significant at the $90 \%$ level, but this time below zero, indicating a slowing down of rule issuance. We also note that, compared to the baseline, the effect of turning the DOI variables "on" appears to have a more substantial effect than the inverse scenario where they are turned "off." In short, for statutes that have a broad delegation of authority, our findings indicate that when internal considerations are primed for an agency to write draft rules, agencies issue them more quickly. Yet, the inverse holds, too.

\section{Other findings}

Several other patterns are of interest in Table 2, Model 1. Take, for instance, the results attached to Unified Government. While this construct is not a focus of our theorising, it is a critical predictor variable in numerous studies focused on the delegation-discretion relationship (Epstein and O'Halloran 1999; Tsebelis 2002; Farhang and Yaver 2016; Revesz and Davis Noll 2019; Bertelli and Doherty 2019). Interestingly, we find no evidence of Unified Government affecting draft rule timing. It is statistically insignificant in Table 2, Model 1 (as well as in Models 2 and 3). Moreover, graphical displays of this variable show no evidence 
that it emerges as significant at any point across analysis time (omitted). While we use a time invariant measure of Unified Government, in analyses not shown, we have swapped out this metric for a time varying one. Again, Unified Government does not emerge as a meaningful predictor variable in the data. ${ }^{9}$

Time to Presidential Election is statistically significant in all three models; however, it changes signs across the model specifications and holds little substantive effect on NPRM issuance when we compare it graphically to the baseline models (omitted). Partisan Coalition, Initial Administration and the interaction between Time to Presidential Election and Initial Administration are not returned as statistical and/or substantively important variables across the model specifications. These findings are derived from many decades of agency policymaking; however, the data's conclusion point in 1990 may affect the generalisability of the results to more modern times. In the case of Initial Administration, for instance, research on the administrative presidency (Moe 1985; Durant 1992; Moe and Wilson 1994) suggests that the tools of the presidency have advanced across time and in ways that may make the modern president a more potent political principal of the federal bureaucracy than in the past (Lewis 2008; Resh 2016).

In results not shown, we also undertook the time-intensive step of integrating variables measuring the presence of each statute's enacting coalition into the main model specification. First, we collected data on every member of the House and Senate who was listed as cosponsor for each DOI delegating statute. We then created time-varying variables for the remaining cosponsors in both the House and Senate across analysis time and reestimated our models. To account for potential censoring because cosponsorship was substantially limited in the House before 1967 (Koger 2003), we reestimated the models starting in $1967 .{ }^{10}$ These additional variables did not increase the contemporaneous risk of draft rule promulgation. Second, we collected data for every House and Senate member who voted for the DOI delegating statutes at passage and then tracked when these members left office. In doing so, we were able to assess which members of the enacting coalitions for each statute remained in office across our full-time analysis (i.e. 1950-1990). Similar to the results above, having a majority of the original enacting coalition (i.e. those voting for statute passage in the House or Senate) still in Congress at any point across time does not increase the risk of NPRM issuance. ${ }^{11}$

\section{Conclusion}

We live in an era of delegated lawmaking. And this observation is perhaps best illustrated in our lived experience: people in the US are much more likely to interact

\footnotetext{
${ }^{9}$ It also does not appear to be the case that Congress uses narrow delegations of authority to constrain the bureaucracy at higher rates during divided government than during unified government. For instance, a $\chi^{2}$ test for the use of narrow versus board delegations based on divided government fails to return a relationship in the data.

${ }^{10}$ Some limits on bill cosponsorship in the House continued after 1967 (Koger 2003). Thus, to undertake the additional analysis, we excluded three statutes in our datasets that had more than 25 House cosponsors after 1967. The results are consistent with or without the inclusion of these three statutes.

${ }^{11}$ Similar findings emerge when focused on different cut points, such as a filibuster proof majority in the Senate or supermajorities in either the House or Senate (omitted).
} 
with the policy decisions made by public agency officials than those made by elected legislators (Kaufman 2001). "Indeed, regulations frequently play a more direct role than statutes in defining the public's legal rights and obligations" (Manning 1996). Or, as Mashaw (1999) puts it, "Much of public law is legislative in origin but administrative in content." We study the connection between the legislative origins and the administrative manifestations of public policy in this article. In doing so, we shed new theoretical and empirical light on the link between the congressional delegation of policymaking authority and agency discretion.

When does legislation trigger regulation? We conceptualise agency policy responsiveness via the timing of draft agency rules, and we theorise a distinction between statutes that provide a narrow delegation of autonomy from those that provide a broad delegation. Importantly, we suggest that this statutory difference is a parsimonious way to understand the scope of the original legislative act, and we expect it to hold policy effects for the timing of regulations. Specifically, due to Congress' (and the courts') many review powers, when Congress expressly directs an agency to promulgate a rule, we anticipate a quickened agency reply. However, when Congress provides greater discretion to an agency - such as authorising that it "may" issue a rule - we hypothesise the opposite effect. We then provide the first quantitative examination of the timing of agency regulations in response to varying congressional delegations of policymaking authority. We use data from almost 350 statutes across four decades, which are matched up with thousands of agency rules. We focus on the legally binding policy actions of the US. DOI, which has a wide-ranging regulatory mandate. Our analyses allow us to simultaneously measure the efficacy of numerous commonly referenced drivers of bureaucratic responsiveness, and we employ innovative event history methods.

Our primary results provide much needed new evidence with regard to the timing of the legislature's statutory demand for regulation to the bureaucracy's supply of regulation. Specifically, we find strong evidence that statutory breadth matters to rule timing. Statutes that obligate agencies to write rules illicit a much quicker regulatory reply from agencies than those that provide permissive grants of regulatory authority. Indeed, almost $50 \%$ of statutes with a narrow delegation produce a rule within a one-year time period. These findings are particularly noteworthy because changes to statutory wording do not require significant congressional resources but do appear to hold substantial effects on rulemaking. Moreover, when Congress combines this type of obligatory delegation language with other signals of congressional attention - before and after a statute is passed - agency responsiveness is achieved even more quickly. For cases when Congress provides a broad delegation of authority in a statute, we uncover evidence for our hypothesis that internal agency considerations are key drivers of rule timing. When taken together, these findings paint a new picture of the connection between delegation and discretion.

This article advances knowledge by providing new theorising and evidence, and hence, it provides a critical reply to West and Raso's (2013) calls for a greater focus on the role of Congress in directing agency rulemaking. We have known for some time that agencies hold a great deal of control over the timing of agency policymaking (Carpenter et al. 2012; Sunstein and Vermeule 2014; Potter 2017). We have also known that the timing of agency regulations is a policy and a political act, which is 
often controversial and consequential (Revesz and Davis Noll 2019). Our findings here indicate that Congress - in its original delegation regime choice - can hold great influence over that timing, and as a result, over agency policy responsiveness. Thus, our article provides one potential solution to the so-called "democratic deficit" that accompanies the gap in time between delegation and regulation (Adler and Walker 2020).

Yet, our study is certainly not the last word on this subject. For instance, more research is needed to extend the article's empirical analyses, across time and to multiple departments. We focus, for instance, on the administrative state immediately following the implementation of the APA; yet additional work is needed to see how these patterns play out today. It could be that in more modern times the practice of using the bureaucracy for its policy expertise has largely given way to other rationales for narrow or broad statutory delegation to agencies. In our contemporary world, for instance, Congress may use the bureaucracy to increasingly shift policy decisionmaking to agencies as a means to duck tough decisions (Weimer 2006; Hood 2010). We have no way to test this hypothesis in our data. However, the extension of our approach in this article to more recent rulemaking activity would be an excellent first step toward teasing out modern delegatory practice. Moreover, our focus here is on legislative statutes that delegate new rulemaking authority to public agencies and the timing of the first agency proposed regulation that employs this delegated discretion. Future work ought to incorporate insights from Bertelli and Doherty (2019) on the issue of reoccurring regulatory decisionmaking.

The hypotheses proposed and tested here also ought to be assessed in additional settings for their generalisability. For instance, our focus on DOI does not allow us to tease apart how presidential agency alignment (Clinton et al. 2012) may affect an agency's promulgation of draft rules, or how the propensity of court interventions might affect an agency's timing calculus. As a result, cross-department data are needed to explore such scenarios empirically. Moreover, similar research in the American states is needed, which, if accomplished, would allow for an evaluation of the theory we propose, as well as its interaction with the diversity present across state legislative institutions (including the presence of sunset or review provisions in regulatory authorisations in some states). Expansion of the work is also needed to yield greater insight into the connection between the bureaucracy's internal considerations and rule timing. For instance, we focus on DOI's regulatory experience and resources; however, other factors may also affect regulatory timing, especially for the broad delegations, such as the bureaucracy's prioritisation of its on-going relationship with organised interests (Golden 1998; Yackee 2006; West and Raso 2013), agency insulation (Bertelli and Doherty 2019) or other contemporaneous political factors (Acs 2015). Additionally, while our emphasis is on legislative agency relations, the president's role in the regulatory process is receiving increased scholarly attention (e.g. Haeder and Yackee 2018; Revesz and Davis Noll 2019). Future work must integrate the president more fully into the theorising and empirical assessments of regulatory timing. Finally, there is also growing evidence that agencies often avoid the standard rulemaking process and instead may issue policy decisions via guidance documents (Raso 2010; Haeder and Yackee 2020c), which may be a different tool for fulfilling congressional demand for regulation. 
The normative implications of our work are also far from settled. We know now that when Congress provides a clear delegation of regulatory authority, government agencies, at least those in our data set, tend to provide a speedy regulatory reply. This implies that legislation has a strong hold over regulation. Some observers will surely see this as a positive sign of congressional control of the bureaucracy. Yet, others may see the modal type of authorisation - broad delegations - to be problematic. After all, once rulemaking authority has been transferred, it is rarely rescinded and can be used at almost any point in time. Some will worry that such delegations are an abdication of lawmaking to a largely unelected and potentially unaccountable bureaucracy. Still others will view these same results as benign, suggesting that Congress often purposefully provides broad delegations. In doing so, it properly transfers power to an informed and expert bureaucracy to pursue its public mission, while balancing the need for delegation with democratic responsiveness and needed policy flexibility. Yet, regardless of what one sees - be it a handmaiden or not - this article adds new evidence to the scholarly and practitioner discussions by extending knowledge around a key debate in political science and policymaking: the relationship between delegation and discretion.

Supplementary material. To view supplementary material for this article, please visit https://doi.org/10. 1017/S0143814X21000180

Data Availability Statement. Replication materials are available at https://doi.org/10.7910/DVN/6RGQ88

\section{References}

Aberbach JD (2001) Keeping a Watchful Eye: The Politics of Congressional Oversight. Washington, DC: Brookings Institution Press.

Acs A (2015) Which Statute to Implement? Strategic Timing by Regulatory Agencies. Journal of Public Administration Research and Theory, 26(3): 493-506.

Adler JH and Walker CJ (2020) Delegation and Time. Iowa Law Review, 105, 1931-1993.

Ando AW (1999) Waiting to Be Protected under the Endangered Species Act: The Political Economy of Regulatory Delay. Journal of Law and Economics, 42(1): 29-60.

Balla SJ (1998) Administrative Procedures and Political Control of the Bureaucracy.. American Political Science Review, 92(3): 663-673.

Bawn K (1997) Choosing Strategies to Control the Bureaucracy: Statutory Constraints, Oversight, and the Committee System. Journal of Law, Economics, and Organization, 13(1): 101-126.

Bertelli AM and Doherty KM (2019) Setting the Regulatory Agenda: Statutory Deadlines, Delay, and Responsiveness. Public Administration Review, 79(5): 710-720.

Boushey GT and McGrath RJ (2017) Experts, Amateurs, and the Politics of Delegation in the American States. Journal of Public Administration, Research, and Theory, 27(1): 85-103.

Callander S and Krehbiel K (2014) Gridlock and Delegation in a Changing World. American Journal of Political Science, 58(4): 819-834.

Carpenter D, Chattopadhyay J, Moffitt S and Nall C (2012) The Complications of Controlling Agency Time Discretion: FDA Review Deadlines and Postmarket Drug Safety. American Journal of Political Science, 56(1): 98-114.

Carpenter DP (2002) Groups, the Media, Agency Waiting Costs, and FDA Drug Approval. American Journal of Political Science, 46(3): 490-505.

Carpenter DP (2004) Protection without Capture: Product Approval by a Politically Responsive, Learning Regulator. American Political Science Review, 98(4): 613-631.

Clinton JD, Bertelli AM, Grose CR, Lewis DE and Nixon DC (2012) Separation of Powers in the United States: The Ideology of Agencies, Presidents, and Congress. American Journal of Political Science, 56(2): 341-354. 
Copeland CW (2010) Rulemaking Requirements and Authorities in the Dodd-Frank Wall Street Reform and Consumer Protection Act. Washington, DC: Congressional Research Service.

Crawford SES and Ostrom E (1995) A Grammar of Institutions. American Political Science Review, 89(3): 582-600.

Durant RF (1992) The Administrative Presidency Revisited: Public Lands, the BLM, and the Reagan Revolution. Albany, NY: State University of New York Press.

Epstein D and O'Halloran S (1999) Delegating Powers: A Transaction Cost Politics Approach to Policy Making under Separation of Powers. New York: Cambridge University Press.

Farhang S and Yaver M (2016) Divided government and the fragmentation of American law. American Journal of Political Science, 60(2): 401-417.

Ferejohn J and Shipan C (1990) Congressional Influence on Bureaucracy. Journal of Law, Economics, \& Organization, 6, 1-20.

Freeman J and Spence DB (2014) Old Statutes, New Problems.. Pennsylvania Law Review, 1-93(10).

Golden MM (1998) Interest Groups in the Rule-Making Process: Who Participates? Whose Voices Get Heard? Journal of Public Administration Research and Theory, 8(2): 245-270.

Golden MM (2003) "Who Controls the Bureaucracy? The Case of Agenda Setting." Unpublished manuscript.

Haeder SF (2019) The Demise of Community Responsibility: Unintended Consequences of Coverage Expansions on California Public Hospitals. Journal of Health Politics, Policy and Law, 44(2): 173-219.

Haeder SF and Yackee SW (2015) Influence and the Administrative Process: Lobbying the U.S. President's Office of Management and Budget. American Political Science Review, 109(3): 507-522.

Haeder SF and Yackee SW (2018) Presidentially Directed Policy Change: The Office of Information and Regulatory Affairs as Partisan or Moderator? Journal of Public Administration Research and Theory, 28(4): 475-488.

Haeder SF and Yackee SW (2020a) A Look Under the Hood: Regulatory Policymaking and the Affordable Care Act. Journal of Health Politics, Policy and Law, 45(5): 771-86.

Haeder SF and Yackee SW (2020b) Out of the Public's Eye? Lobbying the President's Office of Information and Regulatory Affairs. Interest Group \& Advocacy, 9(3): 410-424.

Haeder SF and Yackee SW (2020c) Policies that Bind? The Use of Guidance Documents by Federal Agencies. Journal of Health and Human Services Administration, 43(2).

Haeder SF and Yackee SW (2021) "Replication Data for: Handmaidens of the Legislature? Understanding Regulatory Timing." Harvard Dataverse.

Hill CJ and Lynn LE Jr. (2015) Public Management: Thinking and Acting in Three Dimensions. Washington, DC: CQ Press.

Hood C (2010) The Blame Game: Spin, Bureaucracy, and Self-Preservation in Government. Princeton, NJ: Princeton University Press.

Huber GA (2007) The Craft of Bureaucratic Neutrality: Interests and Influence in Governmental Regulation of Occupational Safety. New York: Cambridge University Press.

Huber JD and McCarty N (2004) Bureaucratic Capacity, Delegation, and Political Reform. American Political Science Review, 98(3): 481-494.

Huber JD and Shipan CR (2002) Deliberate Discretion?: The Institutional Foundations of Bureaucratic Autonomy. New York: Cambridge University Press.

Huber JD, Shipan CR and Pfahler M (2001) Legislatures and Statutory Control of Bureaucracy. American Journal of Political Science, 45(2): 330-345.

Johnson SM (2013) Sue and Settle: Demonizing the Environmental Citizen Suit. Seattle University Law Review, 37, 891-937.

Kaufman H (2001) Major players: Bureaucracies in American government. Public Administration Review, 61(1): 18-42.

Kerwin CM and Furlong SR (2018) Rulemaking: How Government Agencies Write Law and Make Policy, 5th ed Washington, DC: CQ Press.

Koger G (2003) Position taking and cosponsorship in the US House. Legislative Studies Quarterly, 28(2): 225-246.

Lambert PC and Royston P (2009) Further Development of Flexible Parametric Models For Survival Analysis. The Stata Journal, 9(2): 265-290. 
Lavertu S and Weimer DL (2009) Integrating Delegation into the Policy Theory Literature. Policy Studies Journal, 37(1): 93-102.

Lavertu S and Yackee SW (2012) Regulatory Delay and Rulemaking Deadlines. Journal of Public Administration Research and Theory, 24(1): 185-207.

Lewis DE (2008) The Politics of Presidential Appointments: Political Control and Bureaucratic Performance. Princeton, NJ: Princeton University Press.

Lewis DE (2011) Presidential Appointments and Personnel. Annual Review of Political Science, 14, 47-66.

Lowande K (2019) Politicization and Responsiveness in Executive Agencies. The Journal of Politics, 81(1): 33-48.

MacDonald JA (2010) Limitation Riders and Congressional Influence over Bureaucratic Policy Decisions. American Political Science Review, 104(4): 766-782.

Manning JF (1996) Constitutional Structure and Judicial Deference to Agency Interpretations of Agency Rules. Columbia Law Review, 96, 612-696.

Mashaw JL (1999) Greed, Chaos, and Governance: Using Public Choice to Improve Public Law. New Haven, CT: Yale University Press.

Maynard-Moody SW (1998) Exorcising the Ghost of the Politics-Administration Dichotomy: An Institutional Theory of Administration Policy Making. International Journal of Public Administration, 21(6-8): 1031-1054.

McCubbins MD (1985) The Legislative Design of Regulatory Structure. American Journal of Political Science, 29(4): 721-748.

McCubbins MD (1999) Abdication or Delegation-Congress, the Bureaucracy, and the Delegation Dilemma. Regulation, 22, 30-37.

McCubbins MD, Noll RG and Weingast BR (1987) Administrative Procedures as Instruments of Political Control. Journal of Law, Economics, \& Organization, 3(2): 243-277.

McCubbins MD, Noll RG and Weingast BR (1989) Structure and Process, Politics and Policy: Administrative Arrangements and the Political Control of Agencies. Virginia Law Review, 75(2): 431-482.

McCubbins MD and Schwartz T (1984) Congressional Oversight Overlooked: Police Patrols versus Fire Alarms. American Journal of Political Science, 28(1): 165-179.

Miller GJ (2005) The Political Evolution of Principal-Agent Models. Annual Review of Political Science, 8(1): 203-225.

Moe TM (1985) The Politicized Presidency. In Chubb J. E. and Peterson P. E. (eds.), The New Direction in American Politics. Washington, D.C.: Brookings Institution Press.

Moe TM and Wilson SA (1994) Presidents and the Politics of Structure. Law and Contemporary Problems, $57,1-44$.

Moffitt SL (2014) Making Policy Public: Participatory Bureaucracy in American Democracy. New York: Cambridge University Press.

Posner EA and Vermeule A (2002) Interring the Nondelegation Doctrine. University of Chicago Law Review: 172162.

Potter RA (2017) Slow-rolling, Fast-tracking, and the Pace of Bureaucratic Decisions in Rulemaking. Journal of Politics, 79(3): 841-855.

Potter RA (2019) Bending the Rules: Procedural Politicking in the Bureaucracy. Chicago, IL: University of Chicago Press.

Raso CN (2010) Strategic or Sincere? Analyzing Agency Use of Guidance Documents. Yale Law Journal, 119, 782-824.

Resh WG (2016) Rethinking the Administrative Presidency: Trust, Intellectual Capital, and AppointeeCareerist Relations in the George W. Bush Administration. Baltimore, MD: Johns Hopkins Press.

Revesz R and Davis Noll B (2019) Regulation in Transition. Minnesota Law Review, 104.

Rosenbloom DH (2000) Building a Legislative-Centered Public Administration: Congress and the Administrative State, 1946-1999. Tuscaloosa: University of Alabama Press.

Rosenbloom DH (2018) Administrative Law for Public Managers. New York: Routledge.

Rourke FE (1984) Bureaucracy, Politics, and Public Policy. Boston, MA: Little Brown and Company Press.

Royston P (2001) Flexible Parametric Alternatives to the Cox Model, And More. The Stata Journal, 1(1): 1-28. 
Royston P and Lambert PC (2011) Flexible Parametric Survival Analysis Using Stata: Beyond the Cox Model. College Station, TX: Stata Press.

Royston P and Parmar MKB (2002) Flexible Parametric Proportional-Hazards and Proportional-Odds Models for Censored Survival Data, with Application to Prognostic Modelling and Estimation of Treatment Effects. Statistics in Medicine, 21(15): 2175-2197.

Shepsle KA (1992) Bureaucratic Drift, Coalitional Drift, and Time Consistency: A Comment on Macey. Journal of Law, Economics, \& Organization, 8, 111-118.

Shipan CR (2004) Regulatory Regimes, Agency Actions, and the Conditional Nature of Congressional Influence. American Political Science Review, 98(3): 467-480.

Sunstein CR and Vermeule A (2014) The Law of Not Now: When Agencies Defer Decisions. Georgetown Law Journal, 103, 157-195.

Tsebelis G (2002) Veto Players: How Political Institutions Work. Princeton, NJ: Princeton University Press.

Utley RM and Mackintosh B (1989) The Department of Everything Else: Highlights of Interior History. Washington, DC: US Department of the Interior.

Walters DE (2019) Capturing Regulatory Agendas?: An Empirical Study Of Industry Use Of Rulemaking Petitions.. Harvard Environmental Law Review, 42, 175-223.

Weimer DL (2006) The Puzzle of Private Rulemaking: Expertise, Flexibility, and Blame Avoidance in U.S. Regulation. Public Administration Review, 66(4): 569-82.

Weingast BR (2005) Caught in the Middle: The President, Congress, and the Political-bureaucratic System. In Aberbach J. D. and Peterson M. A. (eds.), The Executive Branch. New York: Oxford University Press.

West WF (1995) Controlling the Bureaucracy: The Theory and Practice of Institutional Constraints. Armonk, NY: M.E. Sharpe.

West WF and Raso C (2013) "Who Shapes the Rulemaking Agenda? Implications for Bureaucratic Responsiveness and Bureaucratic Control." Journal of Public Administration Research and Theory, 23(3): 495-519.

Wood BD and Waterman RW (1991) "The Dynamics of Political Control of the Bureaucracy." American Political Science Review, 85(3): 801-828.

Yackee JW and Yackee SW (2010) Administrative Procedures and Bureaucratic Performance: Is Federal Rule-making "Ossified"? Journal of Public Administration Research and Theory, 20(2): 261-282.

Yackee JW and Yackee SW (2016) From Legislation to Regulation: An Empirical Examination of Agency Responsiveness to Congressional Delegations of Regulatory Authority. Administrative Law Review, 68, 395-443.

Yackee SW (2006) Sweet-Talking the Fourth Branch: The Influence of Interest Group Comments on Federal Agency Rulemaking. Journal of Public Administration Research and Theory, 16(1): 103-124.

Yaver M (2015) When Do Agencies Have Agency? The Limits of Compliance in the EPA. Social Science Research Network.

Cite this article: Haeder SF and Yackee SW (2022). Handmaidens of the legislature? Understanding regulatory timing. Journal of Public Policy 42, 298-322. https://doi.org/10.1017/S0143814X21000180 